\title{
第71 回日本体力医学会大会国際セッション参加報告 \\ Participation Report on the International Session at the 71st Annual Meeting of the Japanese Society of Physical Fitness and Sports Medicine
}

\author{
早稲田大学スポーツ科学学術院
}

日本体力医学会渉外委員会 国際セッション係＼cjkstart宮下 政 司

2016年 9 月 23 日（金）から 9 月 25日（日）まで,いわて県民情報交流センター (アイーナ)·盛岡地域交流センター 市民文化ホール（マリオス）にて第71回日本体力医学会大会が開催されました．以下，大会プログラムの一部で ある国際セッションについて報告致します。

国際セッションは, 大会 2 日目 9 月 24 日（土）の 10 時から 12 時までA会場 盛岡地域交流センター市民文化 ホール（マリオス）で行われました，今年の国際セッションでは，日本体力医学会の若手学会員へ公募後，日 本体力医学会渉外委員会で審査を経て採択された 2 名と 2016 年 7 月にオーストリア・ウィーンで開催された第 21 回ヨーロッパスポーッ科学会にてYoung Investigators Awardを受賞した 3 名の計 5 名の演者より発表があ りました. University of Newcastleの Nattai Borges 氏からは，加齢による高強度インターバルトレーニングに 対する酸素動態への影響について, 東京学芸大学の柏原杏子氏からは高齢期における運動と食後代謝について, Victoria UniversityのDanny Christiansen 氏からは虚血運動トレーニングにおけるミトコンドリア輸送系の遺伝 子発現メカニズムについて, 沖縄科学技術大学院大学の青木祥氏からは線条体と運動野からみた運動制御につい て, University of Salzburgの Hans-Peter Wiesinger 氏からは運動種目別からみた膝蓋腱・アキレス腱について, 発表がありました，当日，例年以上に多くの学会員や学会参加者が会場に集まり，質疑応答も含み，活発なセッ ションとなりました，多岐にわたる研究分野にも関わらず座長を快くお引き受けしていただきました，慶應義塾 大学の木村真規先生および立命館大学の後藤一成先生に抢礼申し上げます.

日本体力医学会とヨーロッパスポーツ科学会との交流事業である国際セッションは, 今年で18回目となり長年 にわたり両学術団体の若手研究者間の交流と育成を図っています。日本体力医学会からの公募において, 近年, 博士号を取得したばかりの若手会員のみならず大学院修士課程に在籍する会員からの応募が目立ちます。一方で, 国際セッションへの応募者がこの数年減少傾向にあるため, 引き続き若手会員による良質な研究成果を日本体力 医学会国際セッションから発信していただけるようこの場を㧍借りしましてお願い申し上げます。最後に歴史あ る国際セッションが，今後も若手研究者の交流の場そしてキャリア形成の一助となることを願って拉ります. 